A. Kryzhevskyi, PhD (History), Teaching Assistant,

O. Derii, PhD (Law), Teaching Assistant

Taras Shevchenko National University of Kyiv, Kyiv, Ukraine

\title{
MIGRATION POLICY IN MEDIEVAL AND EARLY MODERN UKRAINE (X - MIDDLE XVIII CENTURY):
} HISTORICAL AND LEGAL ASPECTS

The article analyzes the process of origin and development of migration policy of state entities on Ukrainian lands in the $10^{\text {th }}-\mathrm{first}$ half of the $18^{\text {th }}$ century. The research methodology is to study and analyze the organizational and legal foundations of Ukrainian migration policy during the study period. The validity of theoretical provisions, conclusions, scientific analysis and reliability of the results of the study is ensured by the use of a set of philosophical, general scientific and special scientific methods, namely: historical law, comparative law, historical and functional, formal legal and others. The study was conducted from the perspective of the principles of historicism, objectivity, versatility, complementarity and validity, which created a sound methodological basis for a comprehensive analysis of the subject matter of the study. The scientific novelty is the historical and legal analysis of the basic state-legal elements of migration policy, the identification of peculiarities of their functioning and effectiveness. The scientific novelty is the historical and legal analysis of the basic state-legal elements of migration policy, the identification of peculiarities of their functioning and effectiveness.

The paper states that in the Middle Ages state control was established over the movements of foreigners, ambassadors and merchants. Subsequently, as the socio-economic and political situation changed, the problem of regulating the movement of not only the privileged classes but also the general population arose. It is observed that further strengthening of migration control, both external and internal, comes from the introduction of a passport system. It was found that effective state control over migration, which was based on the passport system, was managed not by the Polish authorities but by the Russian authorities. It was noted that the system of control over the population movement and passport system for some time was established in the territory of Zaporizhzhia Troops, which, in addition, allowed the Sich to emphasize its jurisdiction over the owners of Cossack passports. It has been proved that, since the seventeenth century, the passport has become the main instrument in the implementation of the state migration policy. It is established that it was in the $16^{\text {th }}-17^{\text {th }}$ centuries practices of managed and forced resettlement are being started, which will later be actively used by the Soviet authorities.

Keywords: migration, a migration policy, a passport, a managed resettlement.

Bulletin of Taras Shevchenko National University of Kyiv. Legal Studies, 2020; 2 (113): 44-47

УДК: $340.13: 172 / 177$

DOI: https:doi.org/10.17721/1728-2195/2020/2.113-9
ISSN $1728-2195$

(c) Taras Shevchenko National University of Kyiv, Publishing center "Kyiv University", 2020

М. Панченко, д-р юрид. наук, асист. ORCID ID: 0000-0002-2583-2327

Київський національний університет імені Тараса Шевченка, Київ, Україна

\section{ДИСЦИПЛІНАРНА ВІДПОВІДАЛЬНІСТЬ АДВОКАТА У РАЗІ НЕПРАВОМІРНОГО СПІВРОБІТНИЦТВА ІЗ ПРАВООХОРОННИМИ ОРГАНАМИ}

Досліджено поняття й ознаки неправомірного співробітництва адвоката із правоохоронними органами, обставини, які впливають на суворість дисциплінарного стягнення, що може бути накладене на адвоката внаслідок такого співробітництва. Наведено перелік ознак, за якими слід відрізняти правомірне співробітництво із правоохоронними органами від неправомірного, тобто забороненого, яке тягне за собою дисциплінарну відповідальність для адвоката. З'ясовано, у яких формах може здійснюватися неправомірне співробітництво адвоката із правоохоронними органами. Установлено, що інформація, якою володіє адвокат завдяки своїй професійній діяльності та відповідному статусу, часто використовується співробітниками правоохоронних органів для виконання покладених на них функцій. Досліджено, чи може особа, яка має статус адвоката, бути викривачем у розумінні зу "Про запобігання корупції". Проаналізовано правові висновки Верховного Суду за результатами розгляду адміністративної справи щодо оскарження адвокатом рішення Вищої кваліфікаційно-дисциплінарної комісії адвокатури (ВКДКА) про притягнення його до дисциплінарної відповідальності та накладення дисциплінарного стягнення у вигляді позбавлення права на заняття адвокатською діяльністю за неправомірне співробітництво із правоохоронними органами. Розглянуто аргументи адвокатапорушника та відповідну правову позицію Верховного Суду, який, керуючись актами національного законодавства, визначив дії порушника неправомірними та позовні вимоги відхилив.

Сформовано поняття "неправомірне співробітництво адвоката із правоохоронними органами", визначено його ознаки та викладено пропозиції з підвищення ефективності притягнення адвокатів-порушників до дисциплінарної відповідальності у разі такого співробітництва.

Ключові слова: дисциплінарний проступок, дисциплінарне стягнення, конфідент, викривач, негласні слідчі (розшукові) діï, оперативно-розшукові заходи.

ВСТуП. Інститут адвокатури з моменту свого заснування завжди був і залишається головним способом представництва особи та її інтересів у судах. Відомо, що під час досудового розслідування кримінального провадження у ньому беруть участь як службові особи правоохоронних органів, так і представники захисту адвокати. Очевидним $є$ й той факт, що на багатьох стадіях кримінального провадження $є$ моменти, коли і адвокат, і представники правоохоронних органів співпрацюють задля досягнення певного результату. Проте деякі види такого співробітництва не є правомірними. Більше того, таке неправомірне співробітництво $€$ підставою для притягнення адвоката до дисциплінарної відповідальності. Дана ситуація досить часто зустрічається на практиці, адже особливий статус адвоката у суспільстві, специфічний характері його діяльності $€$ корисними для представників правоохоронних органів у аспекті досягнення необхідних результатів і виконання поставлених перед ними завдань.
Мета даної статті - дослідити межі, поза якими таке співробітництво суперечить нормам національного законодавства, виділити його ознаки, дати визначення такому співробітництву, запропонувати шляхи підвищення ефективності притягнення адвокатів до дисциплінарної відповідальності та виявлення неправомірного співробітництва із правоохоронними органами.

Аналіз останніх досліджень та публікацій. Дослідженням деяких аспектів даного питання були присвячені праці М. І. Іншина, В. А. Гвоздія, В. В. Заборовського, Д. В. Кухнюка та ін.

Погоджуючись із думкою В.А. Гвоздія, вважаємо, що вдосконалення функціонування інституту адвокатури відіграє значну роль у процесі створення ефективної системи захисту прав і свобод людини та свідчить про значний рівень демократизму в державі [1, с. 40].

Щодо поняття "дисциплінарна відповідальність", то таке визначення відсутнє у національному законодавстві. М.І. Іншин, визначаючи поняття дисциплінарної 
відповідальності в аспекті трудового права, з яким ми погоджуємось, підкреслював, що вона полягає у застосуванні відповідних дисциплінарних стягнень [3, с. 329].

Відповідно до визначення, запропонованого Д. В. Кухнюком, дисциплінарна відповідальність адвоката - це особливий вид юридичної відповідальності, що застосовується до адвоката за результатами дисциплінарного провадження, яке здійснюється кваліфікаційно-дисциплінарною комісією адвокатури за вчинення дисциплінарного проступку [4, с. 33].

Проте питання дисциплінарної відповідальності адвоката саме внаслідок взаємодії з правоохоронними органами $€$ малодослідженим, що робить обрану тему досить актуальною.

ВИКЛАД ОСНОВНОГО МАТЕРІАЛУ. По-Перше, необхідно проаналізувати, як національне законодавство визначає поняття "дисциплінарний проступок" та "дисциплінарна відповідальність" адвокатів. Відповідно до ч. 2 ст. 34 зУ "Про адвокатуру та адвокатську діяльність" дисциплінарним проступком визнається:

- порушення вимог несумісності;

- порушення присяги адвоката України;

- порушення правил адвокатської етики; розголошення адвокатської таємниці або вчинення дій, що призвели до її розголошення;

- невиконання або неналежне виконання своїх профресійних обов'язків;

- невиконання рішень органів адвокатського самоврядування;

- порушення інших обов'язків адвоката, передбачених законом.

Отже, неправомірне співробітництво адвоката із правоохоронними органами прямо не вказане як дисциплінарний проступок з боку адвоката. Проте це не $є$ підставою не вважати його таким. У ст. 6 Правил адвокатської етики зазначено, що адвокат зобов'язаний не допускати у своїй професійній діяльності компромісів, що впливали б на його незалежність, з метою догодити державним органам, якщо такі дії перешкоджають належному здійсненню адвокатської діяльності. Зокрема, відповідно до п. 1 ч. 2 ст. 65 КПК України адвокати не можуть бути допитані як свідки у кримінальному провадженні про обставини, які стали їм відомі у зв'язку з виконанням функцій представника чи захисника. Також відповідно до ч. 2 ст. 275 КПК України адвокати не можуть бути залучені до конфіденційного співробітництва під час проведення негласних слідчих (розшукових) дій, якщо таке співробітництво буде пов'язане з розкриттям конфіденційної інформації професійного характеру. Ця заборона стосується й участі адвоката в оперативнорозшукових заходах. Тобто, аналізуючи положення КПК України, ЗУ "Про адвокатуру та адвокатську діяльність" і Правила адвокатської етики, можна зробити висновок, що неправомірне співробітництво адвоката із правоохоронними органами має такі ознаки:

- впливає на незалежність адвокатської діяльності як такої;

- очевидним $€$ конфлікт інтересів; предмет "співробітництва" - знання чи інформація, якими володіє особа, маючи статус адвоката;

- порушення принципу конфіденційності.

Отже, неправомірне співробітництво адвоката із правоохоронними органами - це різновид дисциплінарного проступку, який за своїм характером $€$ діяльністю адвоката з розповсюдження конфіденційної інформації, яка стала йому відома у зв'язку з виконанням професійних обов'язків, участі адвоката в оперативнорозшукових заходах, негласних слідчих (розшукових) діях, що підриває незалежність адвокатської діяльності та порушує її основні принципи.
Неправомірне співробітництво адвоката із правоохоронними органами може здійснюватися у різних формах: передання адвокатом конфіденційної інформації, якою він заволодів у зв'язку з виконанням своїх професійних обов'язків або у вигляді залучення адвоката правоохоронними органами до певних оперативно-розшукових заходів чи негласних слідчих (розшукових) дій. Прикладом першої форми може бути повідомлення адвокатом правоохоронним органам відомостей, що становлять адвокатську таємницю, а другої участь у проведенні оперативно-розшукових заходів, негласних слідчих (розшукових) дій як конфідента (особи, яка залучена правоохоронними органами до конфіденційного співробітництва).

Заслуговує уваги й те, що хоча сам виявлений факт співробітництва адвоката із правоохоронними органами $\epsilon$ достатньою підставою для притягнення його до дисциплінарної відповідальності, існують обставини, що визначають суворість дисциплінарного стягнення, яке може буде накладено.

По-перше, співробітництво може бути системним і довготривалим, тобто може мати місце повторність, системність у характері спільних дій правоохоронних органів і суб'єкта адвокатської діяльності. Практика свідчить, що іноді правоохоронці досить часто та системно співпрацюють із адвокатами як особами, які залучені до конфіденційного співробітництва, що значно полегшує виконання покладених на ці органи завдань.

По-друге, у діях адвоката може мати місце цілеспрямованість. Іншими словами, він співпрацює із правоохоронними органами, чітко розуміючи свої дії й наслідки, до яких вони можуть призвести, бажає та свідомо допускає їх настання, а представники правоохоронних органів не вводили його в оману щодо його ролі, задач i результатів, яких вони прагнуть досягти за його допомогою. Попри те, що на сьогодні досить важко уявити адвоката, який не розуміє наслідків, своєї ролі, задач і результатів, які досягаються при такому "співробітництві" із правоохоронними органами, вважаємо, що ці обставини мають впливати на суворість дисциплінарного стягнення, яке може бути накладено на адвоката у кожному конкретному випадку.

Окрім цього, актуальним є питання допустимості співробітництва адвоката із правоохоронними органами в розумінні зУ "Про запобігання корупції". У цьому нормативно-правовому акті міститься термін "викривач", і відповідно до ч. 1 ст. 1 указаного закону - це фрізична особа, яка за наявності переконання, що інформація $є$ достовірною, повідомила про можливі факти корупційних або пов'язаних із корупцією правопорушень, інших порушень цього закону, вчинених іншою особою, якщо така інформація стала їй відома у зв'язку з ії̈ трудовою, професійною, господарською, громадською, науковою діяльністю, проходженням нею служби чи навчання або іiї участю у передбачених законодавством процедурах, які $€$ обов'язковими для початку такої діяльності, проходження служби чи навчання. Саме з цього визначення і постає запитання - а чи може адвокат бути викривачем?

Аналізуючи законодавство, можна дійти висновку, що адвокат може бути викривачем і мати відповідний статус, але не в усіх аспектах своєї діяльності, оскільки для нього існують відповідні обмеження, установлені ЗУ "Про адвокатуру та адвокатську діяльність" та Правилами адвокатської етики, зокрема щодо розповсюдження конфіденційної інформації, яка стала йому відома у зв'язку з виконанням професійних обов'язків, співробітництва адвоката із правоохоронними органами при проведенні оперативно-розшукових заходів, негласних слідчих (розшукових) дій як конфідента. Проте якщо інформація адвокату стала відома не завдяки його діяльності як адвоката, а, скажімо, громадській чи 
науковій, то відповідних порушень не простежується. Іншими словами, особа, яка має свідоцтво про право на заняття адвокатською діяльністю, може бути викривачем у розумінні ЗУ "Про запобігання корупції", користуючись, у тому числі, привілеями цього статусу, але 3 відповідними обмеженнями, ураховуючи професійний характер своєї адвокатської діяльності.

Розкриваючи питання притягнення адвоката до дисциплінарної відповідальності у зв'язку з неправомірним співробітництвом із правоохоронними органами, на нашу думку, правильним буде підхід, при якому аналізується відповідна судова практика, яка вже наявна, незважаючи на новизну досліджуваного питання, адже воно розв'язується саме в судовому порядку в разі оскарження адвокатом рішення кваліфікаційнодисциплінарної комісії адвокатури про притягнення його до дисциплінарної відповідальності. У Постанові ВС від 31.07.19 (КАС), справа №826/8426/17, позивач звернувся із позовом до суду щодо оскарження рішення ВКДКА про притягнення його до дисциплінарної відповідальності у вигляді позбавлення права на заняття адвокатською діяльністю через неправомірне співробітництво із правоохоронними органами, що виявлялось у повідомленні їм певних обставини та участі у провокаціях.

Свою позицію адвокат обґрунтовував тим, що, на його думку, у його діях не має місце склад дисциплінарного правопорушення, адже він виконував приписи ЗУ "Про запобігання корупції" і своїми діями не порушив ЗУ "Про адвокатуру та адвокатську діяльність" і Правила адвокатської етики. У той же час ВКДКА встановила, що відповідно до фрактичних обставин справи адвокат узяв участь у черговій провокації щодо надання неправомірної вигоди особі, яка займала посаду у Вищій раді юстиції, аби схилити цю особу до прийняття відповідного рішення. Окрім цього, у ході розгляду справи стало відомо, що така діяльність позивача відбувалася неодноразово. ВКДКА вбачала у діях адвоката порушення п. 2, 3, 5 ч. 2 ст. 34 Закону України "Про адвокатуру та адвокатську діяльність": порушення присяги адвоката, правил адвокатської етики та неналежне виконання професійних обов'язків. ВКДКА при прийнятті свого рішення вказувала, що мало місце використання статусу адвоката для здійснення діяльності, не пов'язаної із захистом чи представництвом. Отже, адвоката було позбавлено права на заняття адвокатською діяльністю.

Окружний адміністративний суд м. Києва, який розглядав справу по суті, у задоволенні позовних вимог адвоката відмовив, рішення ВКДКА залишив у силі. Суд апеляційної інстанції також погодився із цим рішенням. Зрештою позивач подав касаційну скаргу, проте Касаційний адміністративний суд у складі Верховного Суду її також не задовольнив і залишив рішення попередніх інстанцій без змін.

При аргументації своєї позиції ВС базував рішення на висновках ВКДКА і загалом із ними погодився. Окрім цього, ВС вбачав у діях скаржника ознаки конфіденційного співробітництва, що також не було правомірним і було порушенням вимог ч. 2 ст. 275 КПК України та п. 3 ч. 1 ст. 23 Закону України "Про адвокатуру та адвокатську діяльність". Також судом було взято до уваги факт систематичного, багаторазового та цілеспрямованого співробітництва позивача із правоохоронними органами в процесі здійснення його профресійної діяльності як адвоката, що є правомірною підставою для позбавлення позивача права на заняття адвокатською діяльністю як найбільш суворого виду дисциплінарного стягнення. Аналізуючи позиції першої та другої інстанції, ВС дійшов висновку, що в даному разі має місце вчинення адвокатом дій, які ставлять його у залежність від інших осіб і підпорядковують його правилам, які прямо суперечать ЗУ "Про адвокатуру та адвокатську діяльність" та Правилам адвокатської етики. Верховний Суд при винесенні свого рішення підкреслював недоречність посилання позивача на ЗУ "Про запобігання корупції", адже виконуючи відповідні вказівки, він діяв саме як представник особи, і тому визначальними тут є приписи спеціального законодавства, яке пов'язане із професійною діяльністю адвоката. У результаті, доповнивши висновки судів попередніх інстанцій, Верховний Суд виніс постанову, у якій залишив касаційну скаргу адвоката без задоволення.

ВИСНОВКИ. Отже, неправомірне співробітництво адвоката із правоохоронними органами $є$ дисциплінарним правопорушенням, яке зазіхає на основні принципи адвокатської діяльності та приписи норм національного законодавства, підриває незалежність адвокатури як такої. Воно полягає в наданні адвокатом інформації правоохоронним органам, яка йому стала відома саме завдяки статусу адвоката і виконанню професійних обов'язків; участі адвоката як конфідента у проведенні оперативно-розшукових заходів, негласних слідчих (розшукових) дій уповноваженими особами правоохоронних органів. При визначенні виду дисциплінарного стягнення враховується тривалість, системність такої взаємодії та її цілеспрямованість. Задля розуміння реальної кількості адвокатів, що співпрацюють із правоохоронними органами, і вжиття заходів із недопущення підриву незалежності професії адвоката пропонується компетентним органам адвокатського самоврядування внести відповідні зміни до своїх положень, якими передбачити можливість повного доступу до єдиного реєстру судових рішень і моніторингу заявників (конфідентів), які мають статус адвоката, з метою прийняття відповідних рішень із притягнення зазначених осіб до дисциплінарної відповідальності.

Список використаних джерел:

1. Гвоздій В.А. Функціональний підхід до призначення органів адвокатського самоврядування як суб'єктів адміністративного права. Львівський науковий форум. Матеріали міжнародної науково-практичної конференції. Концептуальні шляхи розвитку НАУКИ ТА ОСВІТИ. 12 13 лютого 2020 року (частина II). Львів 2020. 65 с.

2. Про адвокатуру та адвокатську діяльність: Закон України від 5 липня 2012 року. Зі змінами від 20.03. 2020. URL: http://zakon.rada.gov.ua/ laws/show/5076-17 (дата звернення: 10.05.2020).

3. Іншин М. І. Трудове право України підручник / за заг. ред. М.І. Іншина, В.Л. Костюка, В.П. Мельника. Вид. 2-ге, перероб. і доп. Київ: Центр учбової літератури, 2016. 472 с

4. Кухнюк Д., Шиленко Б. Дисциплінарна відповідальність за порушення адвокатської етики. Вісник Київського національного університету імені Тараса Шевченка. Серія "Юридичні науки". 2019. №4 С. 31- 35.

5. Правила адвокатської етики, затверджені Звітно-виборним з'їздом адвокатів України від 9 червня 2017 року, зі змінами затвердженими Звітно-виборним з'їздом адвокатів України від 15 лютого 2019 року. URL: http://unba. org.ua/assets/uploads/legislation/pravila/2017-06-09pravila2017 596f00dda53cd.pdf (дата звернення: 10.05.2020).

6. Кримінальний процесуальний кодекс України: Закон України від 13.04.2012 № 4651-VI, зі змінами від 20.04.2020. URL: https://zakon.rada.gov.ua/laws/show/4651-17 (дата звернення: 10.05.2020).

7. Про запобігання корупції: Закон України від 14.10.2014, зі змінами від 19.04.2020 URL: https://zakon.rada.gov.ua/laws/card/1700-18 (дата звернення: 10.05.2020)

8. Єдиний Державний реєстр судових рішень. URL: http://reyestr.court.gov.ua/ (дата звернення: 10.05.2020).

9. Заборовський В.В., Бисага Ю.М., Булеца С.Б. Правовий статус адвоката: проблеми теорії та практики. Ужгород: Видавничий дім "Гельветика", 2019. 650 с

10. Заборовський В.В. Правовий статус адвоката в умовах становлення незалежної адвокатури України. Ужгород: Видавничий дім "Гельветика", 2017. 900 с.

References:

1. Hvozdiy V.A. Funktsionalnyi pidkhid do pryznachennia orhaniv advokatskoho samovriaduvannia yak subiektid administratyvnoho prava [Functional approach to appointing advocate self-government organs as subjects of administrative law]. Lvivskyi naukovyi forum. materialy mizhnarodnoi naukovo-praktychnoi konferentsii. Kontseptualni shliahy rozvytku nauky ta osvity. 12-13 liutoho 2020 roku (chastyna II). Lviv 2020. 65s. (in Ukrainian)

2. Zakon Ukrainy "Pro advokaturu ta advokats'ku diyal'nist'" vid 5 ly'pnya 2012 roku. zi zminamy vid 20.03.2020. URL: http://zakon.rada.gov.ua/ laws/show/5076-17 (in Ukrainian). 
3. Inshyn M. I. Trudove parvo Ukrainy [Labor law of Ukraine]. pidruchnyk / za zahalnoiu redaktsiieiu M. I. Inshyna, V. L. Kostiuka, V. P. Melnyka. Vyd. 2-he, pererob. i dop. Kyiv: Tsentr uchbovoi literatury

2016. 472 s. (in Ukrainian)

4. Kukhnyuk D.V., Shylenko B. Dystsyplinarn vidpovidalnist za porushennia advokatskoi etyky [DISCIPLINARY LIABILITY FOR VIOLATION OF LEGAL ETHICS]. visnyk Kyivskoho natsionalnoho universytetu imeni Tarasa Shevchenka. Seriia "Yurydychni nauky" 2019. №4. S.31-34 (in Ukrainian)

5. Pravy'la advokats'koyi ety'ky' zatverdzheni Zvitno-vy'borny'm z'yizdom advokativ Ukrainy' vid 9 chervnya 2017 roku. [The rules of lawyer's ethics were approved by the Reporting and Election Congress of Lawyers of Ukraine dated June 9, 2017]. URL: http://unba. org.ua/assets/uploads/ legislation/pravila/2017-06-09-pravila-2017_596f00dda53cd.pdf (in Ukrainian). 6. Kryminalnyi protsesualnyi kodeks Ukrainy: Zakon Ukrainy vid 9 chervnia 2017 roku. $\mathrm{Zi}$ zminamy vid 20.04.2020. URL: https://zakon.rada.gov.ua/laws/show/4651-17] (in Ukrainian)
7.Pro zapobihannia koruptsii: Zakon Ukrainy vid 14.10.2014. Zi zminamy vid 19.04.2020. URL:https://zakon.rada.gov.ua/laws/card/1700-18 (in Ukrainian)

8. Yedynyi Derzhavnyi reiestr sudovykh rishen. URL: http://reyestr.court.gov.ua/ ( in Ukrainian)

9. Zaborovskyi V.V., Bysaha Y. M., Buletsa S. B. Pravovyi status advokata: problemy teoriyi ta praktyky [Law status of an advicaye: issues of theory and practice]. - Uzhhorod: Vydavnychyi dim "Helvetyka", 2019. 650s. (in Ukrainian)

10. Zaborovskyi V.V. Pravovyi status advokata $v$ umovakh stanovlennia nezalezhnoi advokatury Ukrainy [Law status of an advocate in the conditions of the formation of independent legal practice of Ukraine ]. Uzhhorod: Vydavnychyi dim "Helvetyka", 2017. 900s.

Received: $15 / 05 / 2020$ 1st Revision: $07 / 06 / 2020$ Accepted: 24/06/2020

M. Panchenko, Dr. of Law, Teaching Assistant

Taras Shevchenko National University of Kyiv, Kyiv, Ukraine

\section{THE ADVOCATE'S DISCIPLINARY RESPONSIBILITY FOR WRONGFUL COOPERATION WITH LAW-ENFORCEMENT BODIES}

This article is devoted to the research on the concept and features of the advocate's wrongful cooperation with law-enforcement bodies and the circumstances that influence the severity of a disciplinary penalty in the result of such cooperation. A list of certain features is given to distinguish the lawful cooperation of an advocate with law-enforcement bodies from the wrongful one, which leads to bringing the advocate to the disciplinary responsibility. The author ascertains the forms in which the wrongful cooperation of an advocate and law-enforcement bodies may occur. The article determines that law-enforcement bodies often use the information that an advocate possesses due to his/her special professional status in order to perform their functions. Besides, the article examines the possibility for an advocate to be a whistleblower under the Law of Ukraine on Prevention of Corruption. The article also analyzes the decision of the Supreme Court in the administrative case where the decision of the Higher Qualification and Disciplinary Bar Commission (HQDB) on bringing the advocate to the disciplinary responsibility and imposing a disciplinary penalty of depriving him the right to advocacy for a wrongful cooperation with law-enforcement bodies is appealed. In this research the attention is paid to the wrongdoer's arguments and the corresponding legal position of the Supreme Court which, having used the acts of the national legislation, determined advocate's actions to be illegal and denied the claimant's demands.

The author defines the category of a "wrongful cooperation of an advocate with law-enforcement bodies", determines its features, and suggests the ways for improving the effectiveness of bringing wrongdoers to the disciplinary responsibility in case of such cooperation.

Keywords: a disciplinary offence, a disciplinary penalty, a confidant, a whistleblower, secret investigatory (inquiry) operations, tracking measures.

Bulletin of Taras Shevchenko National University of Kyiv. Legal Studies, 2020; 2 (113): 47-55

УДК: 342.9

DOI: https:doi.org/10.17721/1728-2195/2020/2.113-10
ISSN 1728-2195

C Taras Shevchenko National University of Kyiv Publishing center "Kyiv University", 2020

М. Плескач, асп.

Київський національний університет імені Тараса Шевченка, Київ, Україна

\section{СПІВВІДНОШЕННЯ ЖИТТЄВО ВАЖЛИВИХ ІНТЕРЕСІВ ЛЮДИНИ, СУСПІЛЬСТВА ТА ДЕРЖАВИ У КОНТЕКСТІ АДМІНІСТРАТИВНО-ПРАВОВОГО ЗАБЕЗПЕЧЕННЯ КІБЕРНЕТИЧНОӤ БЕЗПЕКИ}

Розелянуто основні підходи до розв'язання проблеми збалансування життєво важливих інтересів людини, суспільства та держави при використанні кібернетичного простору засобами адміністративного права. Визначено юридичну сутність і значення співвідношення життєво важливих інтересів людини, суспільства та держави в контексті адміністративно-правового забезпечення кібернетичної безпеки, зокрема належного балансу між правоохоронними інтересами держави і повагою до основних прав людини.

При дослідженні використано такі методи: аналізу - для з'ясування окремих ознак понять "інтерес", "потреба", "суб'єктивне право"; синтезу - при виведенні узагальнених понять, зокрема "інтерес людини при використанні кіберпростору"; порівняльно-правовий - для зіставлення законодавства України та міжнародного законодавства у досліджуваному питанні; класифікації - для визначення можливих життєво важливих прав та інтересів людини у кібернетичному просторі.

Окреслено можливу структуру кібернетичної безпеки людини через сукупність ї̈ важливих прав та інтересів у кібернетичному просторі, серед яких: право на доступ до мережі Інтернет (або на широкосмуговий зв'язок); право на захист персональних даних під час використання кіберпростору; право на захист від агресивних маркетингових технологій у кіберпросторі, заборона спостереження та (або) моніторингу, у тому числі через файли "соокіе", маркери HTTP, HTML5, веб-маяки чи інші технології; право на освіту й на доступ до знань за допомогою використання кіберпростору та ін.

Висновки та пропозиції, викладені у дослідженні, можуть бути використані для вдосконалення спеціальних норм адміністративного та інформаційного законодавства України, зокрема Закону України "Про основні засади забезпечення кібербезпеки України".

Ключові слова: баланс інтересів людини, суспільства та держави; використання кібернетичного простору; публічний інтерес; приватний інтерес.

ВСТУП. Актуальність проблематики. В умовах суттєвого збільшення ролі інформаційних технологій у житті людей, невпинного збільшення їх частки у валовому внутрішньому продукті України, особливо під час криз, епідемій та конфліктів, забезпечення належних безпекових правових, організаційних, технічних основ при використанні таких технологій в інтересах людини, держави, суспільства $€$ надзвичайно важливим питанням. Без сумніву, належний рівень безпеки $є$ однією із базових потреб і відіграє важливу роль у забезпеченні 